JST 8 (2) (2019)
JURNAL SENI TARI
Terakreditasi SINTA 5
http://iournal.unnes.ac.id/siu/index.php/ist

\title{
Estetika Gerak Tari Kuda Lumping di Desa Sumber Girang Kecamatan Lasem Kabupaten Rembang
}

\section{Febrina Sonia Jazilah ${ }^{1}$, Indriyanto $^{2}$ Jurusan Pendidikan Sendratasik, Fakultas Bahasa dan Seni Universitas Negeri Semarang}

\begin{tabular}{l} 
Info Artikel \\
\hline Sejarah Artikel \\
Diterima : 6 September \\
2019 \\
Disetujui : 10 November \\
2019 \\
Dipublikasikan : 27 \\
November 2019
\end{tabular}

Keywords:

Estetika, Gerak, Tari

Kuda Lumping

\begin{abstract}
Abstrak
Tari Kuda Lumping adalah salah satu bentuk seni pertunjukan rakyat yang secara umum cirinya menggunakan properti kuda kepang. Tari Kuda Lumping di Desa Sumbergirang Kecamatan Lasem Kabupaten Rembang memiliki keindahan yang dapat dilihat melaluigeraknya. Keindahan gerak tersebut dapat dilihat melalui pola ruang, waktu, dan tenaga. Tujuan dari penelitian ini yaitu untuk mengetahui dan mendeskripsikan estetika gerak Tari Kuda Lumping Desa Sumbergirang. Metode penelitian ini menggunakan pendekatan deskriptif kualitatif dengan pendekatan etik-emik dan estetis koreografis, dengan teknik pengumpulan data berupa observasi, wawancara dan dokumentasi. Teknik analisis data menggunakan teori Adshead, sedangkan pemeriksaan keabsahan data menggunakan teknik triangulasi sumber. Berdasarkan hasil penelitian yang telah dilakukan gerak sebagai media pokok Tari Kuda Lumping dapat mencerminkan nilai keindahan. Keindahan gerak terbentuk melalui pola ruang, waktu dan tenaga, sehingga Tari Kuda Lumping di Desa Sumbergirang mempunyai keindahan yang khas yang berbeda dengan Tari Kuda Lumping di daerah lain. Estetika gerak Tari Kuda Lumping muncul ketika penari menggerakkan seluruh elemen tubuh dari kepala, badan, tangan dan kaki. Keserasian antara elemen tubuh saat melakukan geraktari menjadi suatu keindahan. Kesan gerak yang terdapat pada Tari Kuda Lumping yaitu energik, lincah, kuat terkadang gerakannya halus, dan juga lembut.

\section{Abstract}

Kuda Lumping Dance is one form offolkperforming arts that generally characterizes using the propertyof a horse braid. The Kuda Lumping dance in Sumbergirang Village, Lasem District, Rembang Regency has a beauty which can be seen through its movements. The beauty of the movements can be seen through the patterns of space, time and energy. This study aims to find out and describe the aesthetic movements of Kuda Lumping Dance inSumbergirang Village. Qualitative descriptive approach with a choreographical and ethical aesthetic approach was used as the research method. The data collected in the form of observation, interviews and documentation. The data were analyzed using Adshead theory, while triangulation techniques used to check the validity of the data. The results of study showed that movements as the main media of Kuda Lumping Dance can reflect the value of beauty. The beauty of the movements is formed through the pattern of space, time and energy, so that Kuda Lumping Dance in Sumbergirang Village has a distinctive beauty that is different from Kuda Lumping Dance in other regions. The aesthetic movement of Kuda Lumping Dance emerged when the dancermoves all bodyelements from the head, body, hands andfeet. The harmony between body elements while performing dance movement creates abeauty. The impression of movement found in Kuda Lumping Dance is energetic, lively, and strong, but sometimes the movements can be soft and also gentle.
\end{abstract}

(C) 2019 Universitas Negeri Semarang

$\bowtie$ Alamat korespondensi:

Gedung B2 Kampus Sekaran, Gunungpati, Semarang, 50229

Email : 1. febson96@gmail.com

2. indriyanto609@gmail.com 
Febrina Sonia Jazilah / Jurnal Seni Tari 8 (2) (2019)

\section{PENDAHULUAN}

Sebuah tari merupakan upaya suatu mewujudkan keindahan melalui susunan gerak dan irama dalam satuan komposisi gerak untuk menyampaikan pesan tertentu. Tari selain sebagai ungkapan ekspresi jiwa manusia yang disalurkan lewat gerak, namun tari juga sebagai bentuk pengalaman keindahan, bentuk simbolis dan sebagai bentuk hiburan (Jazuli 2011:29). Kesenian tidak bisa dipisahkan dengan kebudayaan, karena, kesenian dipandang sebagai salah satu unsur kebudayaan. Seni tari merupakan salah satu wadah yang mengandung unsur keindahan, dimana dapat diserap melalui indera penglihatan (visual) dan indera pendengaran (auditif). Keindahan atau yang sering disebut dengan estetika merupakan segala hal yang meyangkut keindahan yang ada pada penglihatan seseorang. Pandangan itu sendiri dapat dianggap sebagai sesuatu yang bersifat relatif dan tidak bisa dipastikan sama.

Keindahan tari terdapat dua nilai penting yang perlu diketahui, yaitu nilai instrinsik, dan nilai ekstrinsik. Nilai keindahan intrinsik adalah nilai bentuk seni yang dapat diindera dengan mata, telinga, atau keduanya. Nilai bentuk ini kadangjuga disebut nilai struktur, yakni bagaimana cara menyusun nilai-nilai ekstrinsiknya. Sedangkan nilai ekstrinsik atau nilai bahanya berupa rangkaian peristiwa. Semuanya disusun begitu rupa sehingga menjadi sebuah bentuk yang berstruktur dan dinamai nilai intrinsik. Karya seni tetap harus mengandung keindahan, makna ekstrinsik itulah yang menyebabkan sebuah karya seni dikatakan indah, menyenangkan inderawi, dan menggembirakan batin (Sumardjo 2000:156-157).

Unsur keindahan dalam seni tari dapat dilihat melalui gerak dan proses koreografinya. keindahan juga dapat dilihat melalui elemen-elemen dan isi nya yang meliputi ide, gagasan, suasana, ibarat atau pesan. Unsur-unsur keindahan dalam seni dapat dilihat dari wujud, bentuk atau rupa. Unsur lain yang berperan menimbulkan rasa indah pada pengamat yaitu, keutuhan atau kebersatuan, penonjolan atau penekanan, dan keseimbangan (Djelantik 1999:42-61). Demikian juga tari Kuda Lumping di Desa Sumbergirang Kecamatan Lasem Kabupaten Rembang. Kuda lumping adalah salah satu bentuk seni pertunjukan rakyat yang secara umum cirinya menggunakan properti kuda kepang, yaitu kuda-kudaan dibuat dari bambu yang dianyam. Istilah kesenian rakyat yang memakai kuda kepang menjadi beraneka ragam berdasarkan kesenian tersebut hidup atau berdasarkan kewilayahan.

Kuda lumping juga disebut jeran kepang, yaitu tarian tradisional Jawa yang menampilkan sekelompok prajurit tengah menunggang kuda. Seperti halnya kesenian rakyat pada umumnya, kesenian Kuda Lumping kedudukannya di masyarakat memiliki tiga fungsi, yaitu ritual, pameran atau festival kerakyatan, dan tontonan atau bersifat menghibur, yaitu kepuasan batin semata.

Tari Kuda Lumping merupakan salah satu kesenian tradisional kerakyatan di daerah Jawa Tengah. Ada yang menyebut tarian ini dengan sebutan Kuda Lumping, Kuda Kepang, Jaran Kepang, Jathilan, Ebeg, Sanghyang, dan lain-lain. Di daerah Rembang sendiri biasanya masyarakat lebih mengenal dengan sebutan Kuda Lumping atau Jathilan. Tari Kuda Lumping di Desa Sumbergirang ini sudah ada sejak tahun 2003 dan masih tetap ada sampai sekarang ini. Kesenian rakyat ini dipimpin oleh Bapak Urip selaku pengurus serta ketua dari kesenian rakyat yang ada di Rembang tepatnya yaitu berada di Desa Sumbergirang, Kecamatan Lasem, Kabupaten Rembang. Tari Kuda Lumping ini memiliki keindahan tersendiri jika dimaikan secara rampak dan kompak karena tarian ini ditarikan secara kelompok. Keindahan tarian kuda lumping juga bisa dilihat dari kekompakan penari dalam melakukan gerak-gerak tari. Keindahan lainnya juga dapat dilihat dari penari membawa kuda kepang, serta tata rias dan busana yang dikenakan oleh para penari.

Menurut Prihatini (2010: 24) nilai estetis adalah kemampuan dari suatu karya seni yang mempunyai kepastian untuk dapat menimbulkan kepastian estetis pada diri orang yang mengamatinya. Penilaian keindahan suatu karya seni dapat dilihat dari segi keindahan subjektifyaitu penilaian dari kesan yang timbul pada diri sang pengamat sebagai pengalaman menikmati karya seni. Keindahan objektif yaitu keindahan yang dapat dilihat dari gaya, bentuk, teknik dan biasanya mengabaikan latar budaya dari mana suatu tari atau penata tari itu berasal. Penilaian keindahan sebuah karya seni secara lebih detail, yaitu unsur-unsur objektifitu yang nyata, dapat dilihat, dapat didengar serta dapat dirasakan (Djelantik 1999:165). Variabel keindahan meliputi subjek dan juga objek. Penghayatan estetika memerlukan bukan saja objek, tetapi juga subjek yang mampu menghayati atau mempersepsikarya seni. Darikedua kutubsubjektif 
Febrina Sonia Jazilah / Jurnal Seni Tari 8 (2) (2019)

dan objektif inilah penilaian karya seni sepanjang masa dilakukan (Murgiyanto 2002: 37).

Tari Kuda Lumping di Desa Sumbergirang

Kecamatan Lasem Kabupaten Rembang mempunyai tarian yang dapat dikatakan indah karena memiliki beberapa unsur yang mendukung keindahan tarian tersebut, salah satunya yaitu didukung oleh keindahan gerak sebagai aspek pokok tarinya. Keindahan gerak pada tari Kuda Lumping di Desa Sumbergirang Kecamatan Lasem Kabupaten Rembang dapat dilihat melalui aspek dasarnya yaitu ruang, waktu dan tenaga. Melalui pola ruang, waktu dan tenaga, tari Kuda Lumping di Desa Sumbergirang Kecamatan Lasem Kabupaten Rembang mempunyai keindahan yang khas yang berbeda dengan tari kuda lumping yang lain. Setiap kesenian atau tari tradisional pada setiap daerah memiliki ciri yang berbeda-beda sesuai dengan sosial dan budaya daerah tersebut. Penelitian ini juga mengacu pada Indriyanto (2019) dalam tulisannya yang berjudul The Dynamic of Gambyong PangkurDance Move. Dinamika gerak Tari Gambyong Pangkur dapat dilihat melalui koneksi gerak yang dapat dilakukan oleh elemen tubuh berdasarkan aspek ruang, waktu, dan tenaga.

\section{METODE PENELITIAN}

Penelitian ini menggunakan metode deskriptif kualitatif, dengan menggunakan pendekatan estetis koreografis dan pendekatan etik dan emik. Peneliti menggunakan pendekatan deskriptif kulitatif karena ingin mendiskripsikan hasil keindahan gerak tari Kuda Lumping.

Pendekatan estetis koreografi digunakan oleh peneliti untuk memperoleh gambaran tentang aspek koreografi yaitu aspek dasar gerak tari yang meliputi ruang, waktu, dan tenaga. Pendekatan etik adalah pendekatan berdasarkan pola pikir peneliti. Pendekatan emik adalah pendekatan berdasarkan pola pikir budaya masyarakat. Kaplan dan manners (dalam Endraswara, 2012) memberikan acuan bahwa pendekatan emik adalah pengkategorian fenomena budaya menurut warga setempat (pemilik budaya) sedangkan pendekatan etik adalah kategori menurut peneliti dengan mengacu pada konsep-konsep sebelumnya. Lokasi penelitian ini tertelak di Desa Sumbergirang RT 01 RW 07 Kecamatan Lasem Kabupaten Rembang tepatnya di Paguyuban Sari Langgeng Budoyo yang dipimpin oleh Bapak Urip.
Teknik pengumpulan data dalam penelitian ini adalah menggunakan metode observasi, wawancara dan dokumentasi. Observasi dilaksanakan untuk memperoleh data mengenai bagaimana Estetika Gerak Tari Kuda Lumping di Desa Sumbergirang Kecamatan Lasem Kabupaten Rembang dengan kajian pokok bagaimana Estetika Gerak Tari Kuda Lumping di Desa Sumbergirang Kecamatan Lasem Kabupaten Rembang yang dapat dilihat melalui aspek dasarnya yaitu melalui ruang, waktu dan tenaga. Peneliti melakukan pengamatan terahadap Estetika Gerak Tari Kuda Lumping di Desa Sumbergirang Kecamatan Lasem Kabupaten Rembang. Kegiatan observasi yang dilakukan peneliti terbagi menjadi dua tahap. Tahap pertama yaitu berupa observasi awal (survey) yang berisikan pengecekan lokasi dan sasaran penelitian. Tahap kedua yaitu sebagai penelitian intidengan kegiatan pengumpulan bahan dan data yang dibutuhkan dalam pembahasan masalah obyek yang diamati.

Teknik wawancara yang digunakan dalam penelitian adalah teknik wawancara terpimpin yang sifatnya pribadi, karena dalam wawancara berhadapan langsung dengan orang yang diwawancarai, dengan pedoman pertanyaan yang sudah dipersiapkan yang sesuai dengan tujuan penelitian. Informan yang dilibatkan dalam wawancara adalah narasumber yang mengetahui asal usul tari kuda lumping yaitu pencipta tari dan musik, penari, dan juga masyarakat Desa Sumbergirang Kecamatan Lasem Kabupaten Rembang.

Dokumen hasil penelitian diperoleh untuk memperkuat informasi yang diberikan oleh informan dilakukan dengan cara mencatat, mengambil gambar, video pertunjukan tari Kuda Lumping serta rekaman hasil wawancara. sehingga dokumentasi yang sudah diambil dijadikan sebagai bukti otentik agar hasil penelitian tetap terjaga validitasnya. Dokumen yang peneliti temukan berupa dokumentasi pementasan Tari Kuda Lumping di Desa Sumbergirang Kecamatan Lasem Kabupaten Rembang yaitu berupa foto, video, serta catatan dari narasumber. Relevansi dokumen yang ditemukan dalam penelitian ini yaitu digunakan sebagai salah satu komponen pertimbangan dalam membuat analisis data yang kemudian dipadukan dalam hasil observasi dan wawancara.

Langkah-langkah analisis tari menurut pendapat Adshead (dalam Murgiyanto 2002:9-10) 
adalah (1) Peneliti mencoba mengenali dan mendeskripsikan tentang komponen-komponen pertunjukan tari seperti gerak, penari, aspek visual dan elemen-elemen auditif. Peneliti melakukan pendeskripsian dan pengenalan tentang gerak Tari Kuda Lumping di Desa Sumbergirang Kecamatan Lasem Kabupaten Rembang meliputi aspek dasarnya yaitu ruang, waktu dan tenaga. (2) Peneliti memahami hubungan antara komponen pertunjukan dalam perjalanan ruang dan waktu, bentuk dan struktur koreografi. Peneliti mencoba mengetahui bagaimana nilai estetika gerak Tari Kuda Lumping di Desa Sumbergirang Kecamatan Lasem kabupaten Rembang yang dilihat dari aspek gerak dan nilai estetika gerak dalam Tari Kuda Lumping. (3) Peneliti melakukan interpretasi nilai keindahan gerak Tari Kuda Lumping berdasarkan ruang,waktu, dan tenaga. Langkah analisis dalam penelitian ini juga mengacu pada Indriyanto melakukan langkah deskripsi dan interpretasi dalam tulisannya tentang Pengaruh Tari Jawa pada Tari Baladewan Banyumasan. (Indriyanto 2011:59-66).

Keabsahan data sangatlah penting sebab data yang teruji di dalamnya memuat informasi yang bisa dipertanggungjawabkan. Untuk menguji keabsahan data, maka diperlukan tehnik keabsahan data. Peneliti menggunakan triangulasi yang digunakan untuk memeriksa keabsahan data. Triangulasi menurut Sugiyono (2016: 372) menguraikan triangulasi dalam pengujian kredibilitas ini diartikan sebagai pengecekan data dari berbagai sumber dengan berbagai cara dan berbagai waktu. Peneliti melakukan triangulasi sumber yaitu untuk membandingkan dan mengecek informasi yang ada dalam Tari Kuda Lumping. Peneliti mengambil sumber antara pelatih dengan penari Tari Kuda Lumping hal tersebut dilakukan untuk mencocokan data dari beberapa sumber.

\section{HASIL DAN PEMBAHASAN}

\section{Estetika Gerak tari Kuda Lumping Desa Sumbergirang}

Estetika Tari Kuda Lumping dapat dilihat dari gerak tarian yang terdapat didalamnya. Aspek dasar tari adalah gerak yang meliputi ruang, waktu, dan tenaga. Elemen-elemen tubuh yang digerakkan pada Tari Kuda Lumping meliputi kepala, badan, tangan, dan kaki. Peran elemen tubuh pada Tari Kuda Lumping adalah sebagai alat untuk bergerak membentuk gerakan yang indah. Keindahan Tari Kuda Lumping dapat di lihat melalui penari bergerak dengan menggunakan properti kuda, kesan yang dihasilkan pada gerak Tari Kuda lumping yaitu lembut, halus, terkadang gerakannya energik, lincah dan juga kuat.

Peneliti menganalisis Estetika Gerak Tari Kuda Lumping dengan melihat video dokumentasi. Berdasarkan penelitian yang telah dilakukan gerak yang digunakan dalam Tari Kuda Lumping menggunakan gerak yang halus, lembut terkadang gerakannya energik, dan juga kuat, bertempo pelan dan tidak sukar untuk diingat karena gerakan yang sederhana dan diulang-ulang. Tari Kuda Lumping memiliki perincian gerakyang dapat dilihat melalui unsur gerak Tari Kuda Lumping mulai dari kepala hingga kaki serta deskripsi gerak Tari Kuda Lumping.

\section{Ragam Gerak Tari Kuda Lumping}

Tari Kuda Lumping memiliki ragam gerak Ndegar, Kebyak Jaran, Gendruwo nyondro, Jangkah kanan kiri, jalan gejug maju, geyol mundur, maju adu bahu, dan selak'an jaran. Gerak pada Tari Kuda Lumping masih sederhana, dan gerakkannya cenderung diulang-ulang. Tari Kuda Lumping di Desa Sumbergirang Kecamatan Lasem Kabupaten Rembang merupakan kesenian kerakyatan yang daridulu hingga sekarang tidakada perubahan pada gerakannya. Estetika gerak Tari Kuda Lumping muncul ketika penari menggerakkan seluruh elemen tubuh dari kepala, badan, tangan dan kaki. Keserasian antara elemen tubuh saat melakukan gerak tari menjadi suatu keindahan. Kesan gerak yang terdapat pada Tari Kuda Lumping yaitu energik, lincah, kuat terkadang gerakannya halus, dan juga lembut.

\section{Deskripsi Ragam Gerak Tari Kuda Lumping Gerak Ndegar (4x8 hitungan) dilakukan} dengan Gerakan memutar seperti gerak menunggang kuda. Posisi Kaki kanan melangkah maju ke depan berada di depan kaki kiri. Disaat kaki kanan maju ke depan maka posisi kaki kanan napak, sedangkan kaki kiri agak diangkat ke belakang. Kemudian Posisi tangan kiri memegangi kuda lumping, ketika kaki kanan maju ke depan maka posisi kuda lumping yang dipegang agak didorong kebawah. sedangkan tangan kanan ngepel membawa pecut juga akan di dorong kebawah. Posisi tangan kanan trap cethik sambil membawa pecut. Kemudian disusul dengan kaki kiri yang berada di belakang kaki kanan mengikuti maju ke depan. Ketika kaki kiri napak, maka kaki 
kanan akan diangkat ke depan. Kemudian Posisi tangan kiri memegangi kuda lumping, ketika kaki kiri maju ke depan maka posisi kuda lumping yang dipegang ditarik ketas. sedangkan tangan kanan yang membawa pecut juga akan di tarik keatas. Posisi tangan kanan trap cethik sambil membawa pecut. (Gerakan dilakukan dengan energik, lincah dankuat. Dilakukan secara berulang dengan rician hitungan dan gerak yang sama)

Gerak Kebyak Jaran dilakukan dengan Posisi kaki tanjak kanan, badan degeg kaki mendhak. kaki kanan berada di depan kaki kiri, kemudian tangan kiri yang memegangi kuda lumping di kibaskan ke samping kanan, posisi tangan kanan ngepel memegangi pecut ketika kuda lumping di kibaskan ke samping kanan maka tangan kanan yang memegang pecut akan di tarik ke depan pusar seperti membentuk sudut siku-siku. Kepala ceklek kanan mengikuti kibasan arah kuda lumping yang ke samping kanan. Dilanjutkan dengan tangan kiri yang memegangi kuda lumping di kibaskan ke samping kiri, posisi tangan kanan yang memegangi pecut ketika kuda lumping di kibaskan ke samping kiri maka tangan kanan ngepel memegang pecut akan lurus kebawah seperti sikap siap. Posisi badan mendhak. Posisi kepala ceklek kiri mengikuti kibasan arah kuda lumping yang ke samping kiri. Gerakan dilakukan dengan halus, dan lembut. Dilakukan secara berulang sampai gendruwo mulai masuk dan ikut joget hingga sampai akhirnya gendruwo mulai nyondro 4 penari wanita yang sedang menari.

Gerak Jangkah Kanan Kiri (1x8+1x4 hitungan) dilakukan dengan jangkah kanan, Posisi kaki kanan napak, tumit kaki kanan berada di depan ibu jari kaki kiri berjarak sekitar 2 kepelan tangan, posisi tangan kanan yang membawa kuda lumping agak di dorong kebawah. Posisi kepala toleh kanan mengikuti arah kaki kanan. Lalu pada hitungan ke-2 kaki kanan yang semula napak, kemudian di junjung kaki kanan ke depan kaki kiri sekitar semata kaki di depan kaki kiri. Pada hitungan 3-4junjung kaki kanan ke depan kaki kiri sambil digoyang goyangkan. Posisi tangan kiri yang memegangi kuda lumping digetarkan keatas bawah. Sedangkan posisi kepala menghadap ke arah depan. Dilanjut dengan hitungan 5 jangkah kiri yaitu posisi kaki kanan napak silang ke arah kiri, tumit kaki kanan berada di depan kaki kiri berjarak sekitar 2 kepelan tangan, kemudian posisi tangan kanan yang membawa kuda lumping agak di dorong kebawah. Posisi kepala toleh kiri mengikuti arah kaki kiri. Lalu Hitungan ke-6 kaki kanan yang semula napak silang kekiri, kemudian di junjung ke depan kaki kiri, sekitar semata kaki di depan kaki kiri. Pada hitungan 7-8 kaki kanan yang semula napak silang kekiri di junjung ke depan kaki kiri lalu digoyang-goyangkan. Posisi tangan kiri yang memegangi kuda lumping pada hitungan 7-8 digetarkan keatas bawah. Hitungan 1 di ulangi jangkah kanan. Lalu pada hitungan ke-2 kaki kanan yang semula napak, kemudian di angkat ke depan kaki kiri sekitar semata kaki di depan kaki kiri. Pada hitungan 3-4 kaki kanan di junjung ke depan kaki kiri di kembalikan ke posisi semula yaitu napak di samping kaki kiri. Posisi tangan kiri yang memegangi kuda lumping pada hitungan ke-3 agak ditarik keatas, kemudian hitungan ke-4 didorong kebawah keposisi semula. Posisi tangan kanan yang membawa pecut tetap berada pada trap cethik. Sedangkan posisi kepala menghadap ke arah depan.

Gerak Jalan gejug maju (3×8 hitungan)

Posisi tumit kaki kanan berada di depan ibu jari kaki kiri ketika kaki kanan melangkah maju ke depan maka posisi kaki kanan napak, sedangkan kaki kiri yang berada di belakang kaki kanan gejug kaki kiri dan mengikuti kaki kanan yang maju ke depan. Ketika kaki kanan napak maju ke depan posisi tangan kiri yang memegangi kuda lumping agak di dorong kebawah, tangan kanan memegang pecut berada pada trap cethik. Kemudian pada posisi kaki gejug kiri posisi tangan kiri yang memegangi kuda lumping agak di dorong keatas. Posisi kepala menghadap ke depan. Gerakan dilakukan dengan, halus, dan tegas.

Dilakukan secara berulang dengan rician hitungan dan gerak yang sama

Gerak Geyol mundur (3x8 hitungan) dilakukan dengan kaki kanan melangkah mundur ke belakang bergantian dengan kaki kiri, posisi badan geyol yaitu gerakan pada bagian pinggang ke kanan dan ke kiri. Posisi tangan kanan ngepel membawa pecut ditekuk ke depan dada membentuk sudut siku-siku dibawa ke atas kepala kuda lumping. Tangan kiri yang memegangi kuda lumping di kibaskan ke arah kanan dan kiri. Posisi kepala patahkan ke kanan dan kiri secara bergantian. Gerakan dilakukan dengan energik, dan tegas. Dilakukan secara berulang dengan rician hitungan dan gerak yang sama.

\section{Unsur Gerak Tari Kuda Lumping}


Unsur gerak merupakan bagian terkecil yang belum mimiliki makna. Gerak Tari Kuda Lumping terdiri dari unsur gerak kepala, badan, tangan, dan kaki.

Unsur gerak kepala terdiri dari tolehan, toleh kanan, toleh kiri, hadap depan, ceklek, ceklek kanan, ceklek kiri, patahan, [atahan kanan, patahan kiri. Unsur gerak tangan terdiri dari ngepel, kebyak jaran. Unsur gerak kaki terdiri dari mendhak, napak, gejug, junjungan kanan. Unsur gerak kaki terdiri dari geyol dan degeg.

\section{Nilai Keindahan Gerak Tari Kuda Lumping}

Gerakan Tari Kuda Lumping pada Paguyuban Sari Langgeng Budoyo menggunakan pola-pola gerak yang tidak sulit dan cenderung diulang-ulang. Gerak pada Tari Kuda Lumping menggunakan hampir seluruh bagian tubuh dari kepala, badan, tangan hingga kaki. Gerakan tari Kuda Lumping menggunakan ragam gerak yang baku atau yang sudah dari dulu diajarkan. Gerak yang digunakan menggunakan gerak yang bertempokan pelan dan sesekali bertempo cepat. Gerak pada Tari Kuda Lumping ini sederhana, tidak banyak ragam gerak, dan gerakkannya cenderung diulang-ulang.

Tari Kuda Lumping memiliki keindahan tersendiri apabila dimaikan secara rampak dan kompak karena tarian ini ditarikan secara kelompok. Keindahan geraknya dapat dilihat melalui elemen-elemen tubuh mulai dari gerak kepala, gerak badan, gerak kaki, dan gerak tangan. Nilai keindahan gerak Tari Kuda Lumping dapat dilihat melalui aspek dasar gerak tarian yaitu meliputi ruang, waktu, dan tenaga.

\section{Gerak Ndegar}

Ragam gerak Ndegar dilakukan dengan gerakan memutar sepertigerak menunggang kuda dilakukan dengan tempo yang cepat dan gerak yang lincah. gerak kaki kanan melangkah maju ke depan berada di depan kaki kiri dengan volume kecil, bertekanan, dan tempo yang cepat. Disaat kaki kanan maju ke depan maka posisi kaki kanan napak, sedangkan kaki kiri agak diangkat ke belakang dengan level yang tinggi. Sikap elemen tubuh yang menyertainya tangan kiri memegangi kuda lumping, sedangkan tangan kanan ngepel membawa pecut trap cethik. Ragam gerak Ndegar dilakukan pada saat awal penari masuk ke dalam area pentas. Maka dari itu tata hubungan antar gerak dan sikap elemen tubuh gerak Ndegar terkesan lincah.

Gerak ndegar pada elemen kaki bergerak dengan kaki kanan dan kiri melompat bergantian seperti gerak menunggang kuda yang memberikan kesan lincah, kuat dan energik. Begitu juga pada elemen tangan dengan posisi tangan kiri memeganggi kuda lumping dan tangan kanan memegangi pecut menggunakan tenaga yang kuat karena memegangi properti kuda dan juga pecut, hal ini memberikan kesan yang kuat.

Nilai keindahan gerakNdegardapatdilihat melalui aspek ruang, waktu, dan tenaga. Aspek ruang sendiri dapat dilihat dari garis, volume, arah, dan fokus pandangan. Garis pada penari terlihat ketika penari melakukan gerakan menunggang kuda yang dilakukan dengan memutar sehingga membentuk garis melingkar atau lingkaran yang menimbulkan kesan kuat dan lincah. Volume gerak kaki yang lebar memberikan kesan besar dan kuat pada setiap hitungan gerak, ditambah volume gerak tangan yang memegangi kuda dan pecut membuat kesan gerak yang ditimbulkan tegas. Arah atau gerak perpindahan penari memutar dengan 4 kali putaran dengan hitungan 4x8 diawalai dengan salah satu penari masuk kemudian penariyang lainnya mengikutidi belakangnya dengan gerakan memutar yang dilakukan dengan penuh semangat menimbulkan kesan gerak terlihat rampak dan lincah. Fokus pandangan penari dapat dilihat melalui penari pada saat melalukan gerak Ndegar ini banyak menghadap lurus ke arah depan sehingga menimbulkan gerak yang tegas.

Nilai keindahan gerak Ndegar dapat dilihat melalui aspek waktu dilihat dari aspek tempo, ritme, dan durasi. Tempo gerak Ndegar dilakukan dengan tempo yang cepat sehingga menimbulkan kesan gerak yang ramai, lincah dan agresif. Gerak Ndegar menggunakan ritme ajeg sehingga memberikan kesan yang teratur. Durasi pada gerak Ndegar menggunakan durasi yang tidak lama dengan ketukan yang cepat sehingga menimbulkan kesan yang lincah, dan menarik.

Nilai keindahan gerakNdegardapatdilihat melalui aspek tenaga dilihat dari intensitas, aksen/tekanan, dan kualitas. Gerak ndegar menggunakan intensitas yang banyak dalam melakukan setiap gerakan menggunakan gerakan yang besar sehingga menimbulkan kesan gerakan yang semangat dan kuat. Aksen/tekanan gerak Ndegar memiliki tekanan yang kuat sehingga 
menimbulkan kesan gerak yang tegas. Gerak Ndegar memiliki kualitas gerak yang lepas atau menghentak cepat yang memberikan kesan tegas, ageresif, dan kuat.

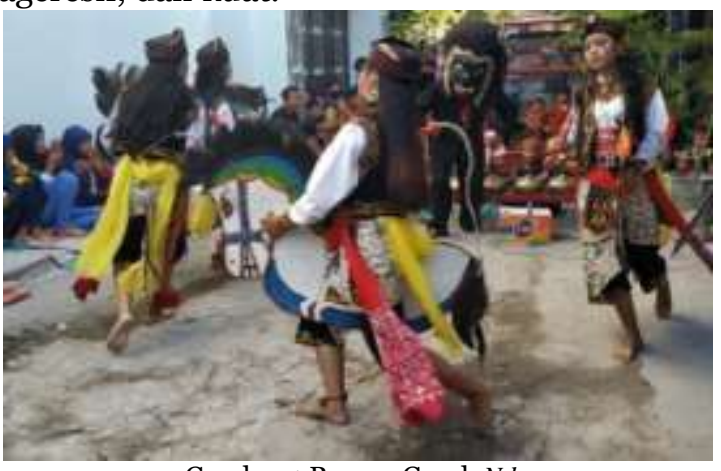

Gambar 1 Ragam Gerak Ndegar

(Foto : Febrina Sonia Jazilah, 10 Juni 2019)

\section{Gerak Kebyak jaran}

Ragam Gerak kebyak jaran dilakukan dengan gerak kaki tanjak kanan, kaki kanan berada di depan kaki kiri dengan volume yang kecil, dan tempo yang lambat. Gerak tersebut disertai dengan gerak kepala ceklek kanan dan kiri dengan intensitas kecil, tempo sedang, dan dilakukan dengan sedikit tekanan. Sikap elemen tubuh yang menyertainya tangan kiri memegangi kuda lumping di kibaskan ke samping kanan dan kiri dengan lemah lembut, dan tempo yang sedang. Tangan kanan ngepel memegangi pecut trap cethik, badan degeg, kaki mendhak. Maka dari itu tata hubungan antar gerak dan sikap elemen tubuh gerak kebyakjaran terkesan lemah lembut.

Gerak kebyak jaran pada elemen tangan bergerak dengan digerakan ke kanan arah samping kanan dan ke kiri arah samping kiri dengan posisi tangan kiri memeganggi kuda lumping dengan menggunakan tenaga yang kuat karena memegangi properti kuda lumping dan juga dilakukan dengan pelan namun sedikit diberi tekanan yang memberikan kesan kuat pada saat membawa properti, dan juga lembut serta mengalun ketika melakukan gerakan. Begitu juga dengan gerakan kaki yang diam dengan posisi kaki tanjak kanan memberikan kesan yang tenang. Elemen kepala pada gerak kebyak jaran memberikan kesan yang lembut.

Nilai keindahan gerak kebyak jaran dapat dilihat melalui aspek ruang, waktu, dan tenaga. Aspek ruang sendiri dapat dilihat dari garis, volume, arah, dan fokus pandangan. Garis pada penari terlihat ketika penari melakukan gerakan kebyak atau mengibaskan kuda ke arah kanan kiri yang dilakukan dengan berdiam ditempat sehingga membentuk garis lurus horizontal yang menimbulkan kesan lembut, dan mengalun. Volumegerak kakiyang sempitmemberikan kesan lembut pada setiap hitungan gerak, volume gerak kepala ceklek kanan dan kiri menimbulkaan kesan gerak yang tegas, ditambah volume gerak tangan yang memegangi kuda dan pecut membuat kesan gerak yang ditimbulkan kuat. Arah atau gerak perpindahan penari tidak bervariasi dengan gerak hanya diam ditempat menghadap depan dan mmbuat garis lurus menimbulkan kesan gerak terlihat lemah lembut. Fokus pandangan penari dapat dilihat melalui penari pada saat melalukan gerak kebyak jaran ini banyak menghadap lurus ke arah depan sehinnga menimbulkan gerak yang lembut dan mengalun.

Nilai keindahan gerak kebyak jaran dapat dilihat melalui aspek waktu dilihat dari aspek tempo, ritme, dan durasi. Tempo gerak kebyak jaran dilakukan dengan tempo yang pelan sehingga menimbulkan kesan gerak yang tenang. Gerak kebyak jaran meggunakan ritme ajeg sehingga memberikan kesan yang teratur, lembut, dan mengalun. Durasi pada gerak kebyak jaran menggunakan durasi yang lama dengan ketukan yang lambat sehingga menimbulkan kesan gerak yang mengalun, dan monoton.

Nilai keindahan gerak kebyak jaran dapat dilihat melalui aspek tenaga dilihat dari intensitas, aksen/tekanan, dan kualitas. Gerak kebyak jaran menggunakan intensitas yang rendah dalam melakukan setiap gerakan menggunakan gerakan yang pelan sehingga menimbulkan kesan gerakan yang lemah lembut. Aksen/tekanan gerak kebyak jaran memiliki tekanan yang rendah sehingga menimbulkan kesan gerak yang lembut, dan mengalun. Gerak kebyak jaran memiliki kualitas gerak yang halus yang dapat dilihat dari gerakan yang dilakukan berulangyang tidak banyak variasi gerak memberikan kesan gerak yang mengalun dan lemah lembut. 


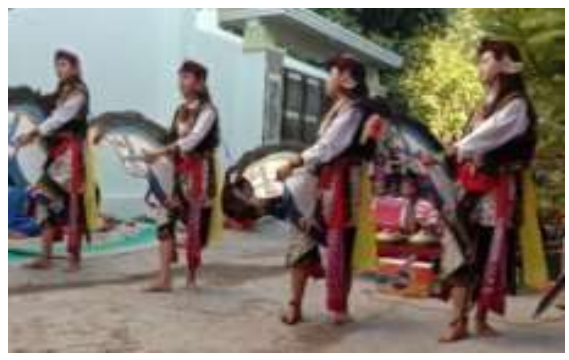

Gambar 2 Ragam Gerak Kebyak Jaran

(Foto : Febrina Sonia Jazilah, 10 Juni 2019)

\section{Gerak Jangkah kanan kiri}

Ragam Gerak jangkah kanan kiri dilakukan dengan posisi kaki jangkah kanan kiri secara bergantian, yaitu dengan posisi awal kaki kanan napak, kemudian junjung kaki kanan, dengan volume yang kecil, kuat, dengan tempo yang cepat . Gerak tersebut disertai dengan gerak kepala toleh kanan dan kiri dengan intensitas kecil, tempo sedang, dan dilakukan dengan diberi tekanan. Sikap elemen tubuh yang menyertainya tangan kiri memegangi kuda lumping dengan kuat. Tangan kanan ngepel memegangi pecut trap cethik, badan degeg, kaki mendhak. Maka dari itu tata hubungan antar gerak dan sikap elemen tubuh gerak jangkah kanan kiri terkesan tegas dan kuat.

Gerak jangkah kanan kiri pada elemen kaki bergerak dengan kaki kanan napak hingga kaki dijunjung atau diangkat kedepan yang memberikan kesan kuat dan juga tegas. Begitu juga pada elemen tangan dengan posisi tangan kiri memeganggi kuda lumping dan tangan kanan memegangi pecut hal ini memberikan kesan yang kuat. Pada elemen kepala pada gerak jangkah kanan kiri mengikuti tolehan jangkah kaki, apabila kaki jangkah kanan maka kepala tolehan kanan, begitu sebaliknya dengan jangkah kiri, sehingga memberikan kesan gerak yang tegas.

Nilai keindahan gerak jangkah kanan kiri dapat dilihat melalui aspek ruang, waktu, dan tenaga. Aspek ruang sendiri dapat dilihat dari garis, volume, arah, dan fokus pandangan. Garis pada penari terlihat ketika penari melakukan gerakan jangkah kaki ke arah kanan kiri yang dilakukan secara bergantian namun penari tetap berada pada tempatnya(tidak berpindah tempat) sehingga membentuk garis lurus yang menimbulkan kesan kuat, dan tegas.
Volume gerak kaki yang tidak terlalu sempit memberikan kesan tegas, volume gerak kepala toleh kanan dan kiri menimbulkaan kesan gerak yang tegas, ditambah volume gerak tangan yang memegangi kuda dan pecut membuat kesan gerak yang ditimbulkan kuat. Arah atau gerak perpindahan penari tidak bervariasi dengan gerak hanya diam ditempat menghadap depan dan mmbuat garis lurus menimbulkan kesan gerak terlihat lembut. Fokus pandangan penari dapat dilihat melalui penari pada gerak jangkah kanan kiri mengikuti tolehanjangkah kaki, apabila kaki jangkah kanan maka kepala tolehan kanan, begitu sebaliknya dengan jangkah kiri, sehingga memberikan kesan gerak yang tegas.

Nilai keindahan gerak jangkah kanan kiri dapat dilihat melalui aspek waktu dilihat dari aspek tempo, ritme, dan durasi. Tempo gerak jangkah kanan kiri dilakukan dengan tempo yang cepat sehingga menimbulkan kesan gerak yang tegas, dan kuat. Gerak jangkah kanan kiri meggunakan ritme yang pergantian gerak kaki yang cepat sehingga memberikan kesan yang kuat, dan teratur. Durasi pada gerak jangkah kanan kiri menggunakan durasi yang cepat sehingga menimbulkan kesan gerakyang energik, dan kuat.

Nilai keindahan gerak jangkah kanan kiri dapat dilihat melalui aspek tenaga dilihat dari intensitas, aksen/tekanan, dan kualitas. Gerak jangkah kanan kiri menggunakan intensitas yang bervariasi dalam melakukan setiap gerakan. Pada saat melakukan gerak jangkah yang diawali dengan kaki kanan napak ke samping, maka intensitas yang digunakan jumlahnya hanyalah sedikit ini menimbulkan kesan gerak yang lembut, dan feminim. Sedangkan ketika kaki kanan mulai dijunjung atau diangkat maka intensitas yang digunakan jumlahnya banyak yang memberikan kesan gerak kuat, dan tegas. Aksen/tekanan gerak jangkah kanan kiri memiliki tekanan yang kuat sehingga menimbulkan kesan gerak yang tegas. Gerak jangkah kanan kiri memiliki kualitas gerak yang bervariasi yang memberikan kesan gerak yang tegas, dan semangat.

\section{Gerak Jalan gejug maju}

Ragam gerak jalan gejug maju dilakukan dengan gerak kaki kanan berada di depan ibu jari kaki kiri ketika kaki kanan melangkah maju ke depan maka posisi kaki kanan napak, sedangkan kaki kiri yang berada di belakang kaki kanan gejug kaki kiri dan mengikuti kaki kanan yang maju ke 
depan dengan volume gerak kakiyang tidakterlalu sempit memberikan kesan tegas, dan tempo yang pelan. Geraktersebut disertai dengan gerak kepala menghadap ke depan. Sikap elemen tubuh yang menyertainya tangan kiri memegangi kuda lumping sedangkan tangan kanan ngepel memegangi pecut trap cethik dengan volume yang sedang, dengan badan degeg, kaki mendhak. Maka

dari itu tata hubungan antar gerak dan sikap elemen tubuh gerak jalan gejug maju terkesan tegas.

Gerak jalan gejug maju pada elemen kaki

bergerak dengan bergantian kaki kanan maju

napak hingga kaki kiri gejug yang memberikan kesan gerak lembut pada saat kaki napak, dan kuat pada saat kaki kiri gejug. Begitu juga pada elemen tangan memberikan kesan gerakyang kuat karena posisi tangan kiri memeganggi kuda lumping dan

tangan kanan memegangi pecut. Pada elemen badan pada gerakjalan gejug maju bergerakdengan tegap memberikan kesan gerak yang tegas.

Nilai keindahan gerak jalan gejug maju dapat dilihat melalui aspek ruang, waktu, dan tenaga. Aspek ruang sendiri dapat dilihat dari garis, volume, arah, dan fokus pandangan. Garis pada penari terlihat ketika penari melakukan gerakan jalan gejug maju dilakukan dengan jalan maju ke depan sehingga membentuk garis lurus vertikal yang menimbulkan kesan lembut dan mengalir. Volume gerak kaki yang tidak terlalu sempit memberikan kesan tegas dan kuat pada gerakan gejug, volume gerak kepala menghadap ke depan menimbulkaan kesan gerak yang lembut, ditambah volume gerak tangan yang memegangi kuda dan pecut membuat kesan gerak yang ditimbulkan kuat. Arah atau gerak perpindahan penari dilakukan dengan gerak jalan maju gejug ke depan dan membuat garis lurus menimbulkan kesan gerak terlihat lembut. Fokus pandangan penari dapat dilihat melalui penari pada gerak jalan gejug maju gerak kepala menghadap ke depan menimbulkaan kesan gerak yangberpusat.

Nilai keindahan gerak jalan gejug maju dapat dilihat melalui aspek waktu dilihat dari aspek tempo, ritme, dan durasi. Tempo gerakjalan gejug maju dilakukan dengan tempo yang pelan sehingga menimbulkan kesan gerak yang mengalun, dan lembut. Gerak jalan gejug maju meggunakan ritme yang pergantian gerak kaki pelan sehingga memberikan kesan yang lembut, juga tegas pada saat gerak gejug. Durasi pada gerak jalan gejug maju menggunakan durasi yang lumayan lama sehingga menimbulkan kesan gerak yang lembut, dan mengalun.

Nilai keindahan gerak jalan gejug maju dapat dilihat melalui aspek tenaga dilihat dari intensitas, aksen/tekanan, dan kualitas. Gerak jalan gejug maju menggunakan intensitas yang bervariasi dalam melakukan setiap gerakan. Pada saat melakukan gerak jalan maju yang diawali dengan kaki kanan napak ke depan, maka intensitas yang digunakan jumlahnya hanyalah sedikit ini menimbulkan kesan gerak yang lembut. Sedangkan kaki kiri gejug ke belakang menggunakan intensitas yang besar yang memberikan kesan gerak kuat, dan tegas. Aksen/tekanan gerak jalan gejug maju memiliki tekanan yang lemah dan beberapa ada yang kuat, sehingga menimbulkan kesan gerak yang mengalun. Gerakjalan gejug maju memiliki kualitas gerak yang tidak banyak variasi yang memberikan kesan gerak yang lembut, mengalun.

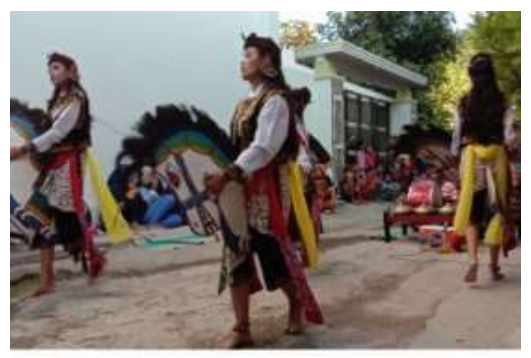

Gambar 3. Ragam Gerak Jalan Gejug Maju

(Foto : Febrina Sonia Jazilah, 10 Juni 2019)

\section{Gerak Geyol mundur}

Ragam gerak geyol mundur dilakukan dengan posisi kaki kanan melangkah mundur ke belakang bergantian dengan kaki kiri dengan volume gerak kaki yang tidak terlalu sempit memberikan kesan kuat, dan tempo yang pelan. Gerak tersebut disertai dengan gerak kepala patahkan ke kanan dan kiri dengan intensitas kecil, tempo cepat, dan sedikit diberi tekanan. Sikap elemen tubuh yang menyertainya tangan kiri memegangi kuda lumping sedangkan tangan kanan ngepel memegangi pecut trap cethik dengan volume yang sedang, dengan badan geyol dilakukan dengan agresif, tempo pelan. Maka 
dari itu tata hubungan antar gerak dan sikap elemen tubuh gerak geyolmundurterkesan agresif.

Gerak geyol mundur pada elemen kaki bergerak dengan bergantian kaki kanan mundur napak bergantian dengan kaki kiri yang memberikan kesan gerak lembut dan feminim. Begitu juga pada elemen badan gerakannya geyol kanan dan ke kiri memberikan kesan gerak yang agresif namun tetap ada sisi lembut. Pada elemen kepala patahan kekanan dan kiri yang memberikan kesan gerak yang bertekanan namun masih terlihat tegas.

Nilai keindahan gerak geyol mundur dapat dilihat melalui aspek ruang, waktu, dan tenaga. Aspek ruang sendiri dapat dilihat dari garis, volume, arah, dan fokus pandangan. Garis pada penari terlihat ketika penari melakukan gerakan jalan mundur dilakukan dengan mundur ke belakang sehingga membentuk garis lurus yang menimbulkan kesan lembut dan mengalir. Volume gerak kaki yang tidak terlalu sempit memberikan kesan tegas dan kuat. Volume gerak tangan besar memberikan kesan yang kuat, dan tegas karena tangan kanan ngepel membawa pecut ditekuk ke depan dada membentuk sudut siku-siku. Volume gerak kepala patahan kanan kiri menimbulkaan kesan gerak yang tegas. Arah atau gerak perpindahan penari dilakukan dengan gerak geyol mundur ke belakang dan membuat garis lurus menimbulkan kesan gerak terlihat lembut. Fokus pandangan penari dapat dilihat melalui penari pada gerak geyol mundurgerak kepala dipatahkan ke kanan kiri menimbulkaan kesan gerak yang tegas.

Nilai keindahan gerak geyol mundurdapat dilihat melalui aspek waktu dilihat dari aspek tempo, ritme, dan durasi. Tempo gerak geyol mundur dilakukan dengan tempo yang pelan sehingga menimbulkan kesan gerak yang mengalun, dan lembut. Gerak geyol mundur meggunakan ritme yang menggunakan pergantian gerak kaki pelan sehingga memberikan kesan yang lembut. Durasi pada gerak geyol mundur lumayan lama sehingga menimbulkan kesan gerak yang lembut, dan mengalun.

Nilai keindahan gerak geyol mundur dapat dilihat melalui aspektenaga dilihat dari intensitas, aksen/tekanan, dan kualitas. Gerak geyol mundur menggunakan intensitas tenaga yang digunakan sedikit dalam melakukan setiap gerakan menggunakan gerakan yang pelan sehingga menimbulkan kesan gerakan yang lemah lembut. Aksen/tekanan gerak geyol mundur memiliki tekanan/aksen yang lemah pada gerak jalan mundur dan beberapa ada yang kuat pada saat tangan kanan memegangi pecut ditekuk ke depan dada, sehingga menimbulkan kesan gerak yang mengalun, sehingga menimbulkan kesan gerak yang lembut, dan mengalun. Gerak geyol mundur memiliki kualitas gerak yang tidak banyak variasi yang memberikan kesan gerak yang lembut, mengalun.

Nilai keindahan gerak geyol mundur dapat dilihat melalui aspek ruang, waktu, dan tenaga. Aspek ruang sendiri dapat dilihat dari garis, volume, arah, dan fokus pandangan. Garis pada penari terlihat ketika penari melakukan gerakan geyol mundur dilakukan dengan jalan mundur sehingga membentuk garis lurus yang menimbulkan kesan lembut dan mengalir. Volume gerak kaki yang tidak terlalu sempit memberikan kesan, volume gerak kepala menghadap ke depan menimbulkaan kesan gerak yang lembut, ditambah volume gerak tangan yang memegangi kuda dan pecut membuat kesan gerak yang ditimbulkan kuat. Arah atau gerak perpindahan penari dilakukan dengan gerak geyolmundur ke depan dan membuat garis lurus menimbulkan kesan gerak terlihat lembut. Fokus pandangan penari dapat dilihat melalui penari pada gerak geyol mundur gerak kepala menghadap ke depan menimbulkaan kesan gerak yang berpusat.

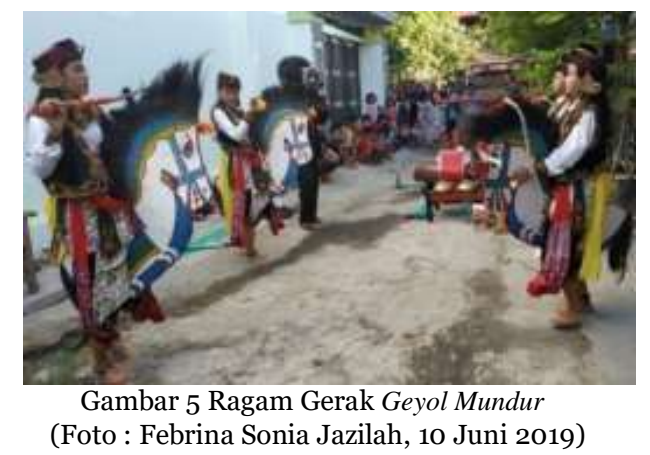

\section{SIMPULAN}

Estetika gerak Tari Kuda Lumping dapat dilihat melalui tata hubungan antar unsur gerak tubuh yaitu dari kepala, badan, tangan dan kaki. Tari Kuda Lumping di Desa Sumbergirang Kecamatan Lasem Kabupaten Rembang memiliki keindahan yang dapat dilihat melalui geraknya. Keindahan gerak tersebut dapat dilihat melalui pola ruang, waktu, dan tenaga sehingga menghasilkan 
nilai keindahan yang khas. Gerak Tari Kuda Lumping dilakukan dengan gerak-gerak kaki dengan volume lebar, dan tempo yang cepat. Gerak tersebut disertai dengan gerak kepala toleh kanan dan kiri dengan intensitas kecil, tempo sedang, dan dilakukan dengan diberi tekanan. Sikap elemen tubuh yang menyertainya tangan kiri memegangi kuda lumping dengan kuat. Tangan kanan ngepel memegangi pecut trap cethik, badan degeg, kaki mendhak. Jadi tata hubungan antar gerak dan sikap elemen tubuh dengan pola ruang, waktu, dan tenaga maka kesan keindahan gerak yang dihasilkan yaitu energik, lincah, kuat namun terkadang gerakannya halus, dan juga lembut.

\section{DAFTAR PUSTAKA}

Djelantik, A.A.M. 1999. Estetika Sebuah Pengntar. Bandung: Masyarakat Seni Pertunjukan Indonesia

Endraswara, suwardi. 2012. Metodelogi penelitian kebudayaan. Yogyakarta. Gadjah mada universiti press.

Indriyanto. 2011. "Pengaruh Tari Jawa Pada Tari Baladewan Banyumasan”. Jurnal Harmonia, Vol. 11, No.1.hlm: 59-66.

. 2019. "The Dynamic of Gambyong Pangkur Dance Move". Advances in social science, education and humanities research, Volume 276.

Jazuli, M. 2011. Sosiologi Seni (Pengantar dan Model Studi Seni). Surakarta: Sebelas Maret University.

Murgiyanto, Sal. 2002. Kritik Tari: Bekal \& Kemampuan Dasar. Jakarta: Ford Foundation Dan Masyarakat Seni Pertunjukan Indonesia.

Prihatini, Arena. 2010. "Simbol dan Nilai Estetis Tata Busana Tari Mbathil di Kabupaten Kudus". Skripsi. Semarang: Universitas Negeri Semarang.

Sugiyono. 2016. Metode Penelitian Pendidikan. Bandung: Alfabet.

Sumardjo, Jakob. 2000. Filsafat Seni. Bandung : ITB. 